ПРИЛОЗИ И ГРАЪА

UDC 821.163.41-6.09 Milanković U.

https://doi.org/10.18485/ms_zmskij.2020.68.1.17

Др Срђан В. Орсић

\title{
ПИСМА УРОША МИЛАНКОВИЋА ИЗ РУКОПИСНЕ ЗАОСТАВШТИНЕ МИЛАНА ШЕВИЋА
}

\begin{abstract}
Писма Уроша Миланковића (Даљ 1800 - Беч 1849) из рукописне заоставштине Милана Шевића, те његова писана коресподенција са Људевитом Гајем, сведоче о приватној преписци као виду породичне и пословне комункације, кроз коју можемо да реконструишемо поједине аспекте свакодневног приватног живота њиховог аутора. Поред до сада већ представљених доступних и сачуваних филозофских дела, али и недавно откривене поезије Уроша Миланковића, сада можемо да упознамо филозофа и као приватну и као јавну личност свога времена: као типичног члана једне српске грађанске породице прве половине деветнаестога века, те као писца посвећеног судбини својих дела.

Кључне речи: Урош Миланковић, Милан Шевић, писма, рукопис, преписка.
\end{abstract}

1. Увод. Пратећи рецепцију дела филозофа Уроша Миланковића (Даљ 1800 - Беч 1849) у двадесетом веку, Иво Тартаља обогатио је наша знања о овом деветнаестовековном аутору, обелодањујући у целости његову до тада тек делимично публиковану и готово сасвим заборављену поезију. Међутим, ненамерну грешку коју је том приликом начинио, називајући извор свога рада „стари мастилом исписани рукопис никада непроученог филозофа Уроша Миланковића“ (ТАРтАљА 2015а: 851) и „оригиналан манускрипт Урошевих песама“" (ТАРтАљА 2015б: 572), исправила је Зорица Хаџић. Увидом у рукописну заоставштину Милана Шевића, у жељи да труд овог ерудитног предратног професора Универзитета у Београду и значајне личности наше књижевне историографије не падну као жртва једног „неспоразума или, пак, недовољне обавештености“ (ХАџић 2017: 16), утврђено је да фотографисани текст песама, који је као прилог присутан у Тартаљином раду, јасно сведочи да је реч о аутографу Милана Шевића. Описујући детаљно поменуту рукописну грађу, Зорица Хаџић истиче: „Дакле, у препису Милана 
Шевића сачувани су стихови Уроша Миланковића које је Тартаља штампао, као и иири йисма која је уйуиио родительима у Даљ, два из 1827. и једно из 1830. (курзив С.О.)“(ХАџић 2017: 17). Иво Тартаља, и сам пишући о корпусу текстова у којем је и поезија пронађена, наводи као најважнија такође иста документа: „А, йоред неколико йисама оиу (курзив С.О.), најважнији део сачуване грађе чине управо стихови под насловом Сочињеније/Уроща Миланковића, мудрословија слищаиееља“" (ТАРтАљА 2015б: 578). У намери да књижевној јавности представимо ова до сада непубликована писма, одабрали смо их као централну тему нашега рада, али ћемо се, пре бављења њима, позабавити потпуним решавањем питања како и зашто је Милан Шевић скупљао и преписивао рукописе Уроша Миланковића. Говорећи о Урошу Миланковићу, контекст његових писама осветлићемо и представљањем истакнутих појединаца породице Миланковић из Даља, која је у низу од више векова давала најбоље представнике српске грађанске класе. На самом крају, наведена писма упоредићемо са преписком Уроша Миланковића и Људевита Гаја, дајући још једну потенцијалну визуру стваралачке и приватне личности овог филозофа.

2. МИЛАН ШЕВИЋ И РУКОПИСНА ЗАОСТАВШТИНА УРОША МИЛАНКОВИЋА. У поменутом тексту, цитирајући пасаж из Усиомена, Доживљаја и сазнања Милутина Миланковића ${ }^{1}$ у којем у јасну везу доводи предратне колеге са београдског Универзитета, Зорица Хаџић демантује још једну констатацију Ива Тартаље, који сматра да „,је грађу о Урошу Миланковићу (сачувану рукописну грађу за коју чак ни Милутин Миланковић није знао) на чување предао Милутинов брат Богдан“" (ТАРтАљА 2015б: 578). Да бисмо дали потпун одговор на питање „због чега је Милан Шевић преписивао рукописе Уроша Миланковића и прикупљао податке о њему“ (ХАџић 2017: 16), навешћемо цео историјат односа породице Миланковић и Милана Шевића, чија сведочанства су нам доступна у штампаној и рукописној грађи.

Прва забележена веза Милана Шевића и породице Миланковић налази се у првој књизи Шевићевих Дневника, где за датум 15. тј. 2. новембар 1910, аутор између осталог бележи: „(...) По подне са В. Муачевићем код Лазе. Саопштио ми је неке податке, које сам забележио (...)“(Шевић 2013: 243). Поменути В. Муачевић, човек је који је најзаслужнији за финансијски опстанак

\footnotetext{
${ }^{1}$ О поменутој рукописној грађи, великан светске научне мисли пише: „У дому чика-Јована чувала се нека писма и мањи списи Урошеви, међу њима и једна песма у стиховима. Оригинали тих списа које сам неко време чувао код себе у Београду пропадоше у Јовановој кући у Даљу, а, вероватно, и њихови преписи што их је поменутом приликом начинио професор Милан Шевић. Он ми рече да су значајни због тога што су, пре Вука, писани чистим народним језиком“ (МилАнковић 1997: 146). Да би ова веза била потврђенија, наведен је и цитат из Дневника Милана Шевића, датиран 29. децембра 1922, у коме се, између осталог, наводи и да је Шевић, при боравку у Новом Саду, био „Поподне опет у Матици, тражио податке о Миловану Јанковићу и о Урошу Миланковићу“ (Шевић 2014: 287).
} 
тада долазеће генерације даљских Миланковића, након преране смрти њиховог оца Милана 1886. године. Васа Муачевић (1851-1927), велепоседник из Осијека, био је рођени ујак и поочим Милутина Миланковића и остале деце своје рано обудовљене сестре Јелисавете. У споменутом сусрету у Бечу, Муачевић и Шевић сусрећу се поред болесничке постеље Лазе Костића. Као човек присутан у политичком и културном животу Двојне монархије, јасно је да је Васа Муачевић знао много занимљивих појединости које су могле бити од користи у раду и истраживањима Милана Шевића.

У другој књизи Шевићевих Дневника, пре дела у којем за будући рад о Урошу Миланковићу Шевић у библиотеци Матице српске у Новом Саду тражи податке, помиње се и сам сусрет Милутина Миланковића и Милана Шевића, 8. новембра 1922, по свему судећи, у просторијама београдског Универзитета: „(...) Предавања. Лепо, свеже. Миланковић ми прибавио многе интересантне податке о Урошу М. и предаће ми их“ (Шевић 2014: 284). Можемо да закључимо да је до размене грађе заиста и дошло и да је том приликом и начињена Шевићева преписка оригиналних докумената. ${ }^{2} \mathrm{Me-}$ ђутим, Милан Шевић, универзитетски професор, књижевни историчар и педагог, преводилац са немачког, француског и енглеског језика, приређивач бројних књига и аутор великог броја књига и уџбеника, (кога је Иво Тартаља сумирао као „мање познатог филозофског и педагошког писца“ (ТАРТАљА 2015б: 578), оп. С.О), коме су бројни савременици пребацивали претеран рад и ренесансну знатижељу, напросто није имао довољно времена да се припремљеном материјалу врати.

3. СУДБИНА РУКОПИСНЕ зАОСТАВШТИНЕ УРОША МИЛАНКОВИЋА. Да више оД темељне припреме за касније писање Милан Шевић није предузео, видимо и по томе што се Милутин Миланковић у својим писмима Марку Малетину, тада уреднику Летиойиса Матице српске, обраћа и моли за помоћ око даљег рада на оставштини свога деда-стрица. Покушај да студију о Урошу Миланковићу напише Васа Стајић није дао резултат ${ }^{3}$, па је Милутин Миланковић

\footnotetext{
${ }^{2}$ Као додатна потврда може да нам послужи и то што се, испод машински прекуцаног животописа Уроша Миланковића који се такође налази међу документима у Шевићевој фасцикли Урощ Миланковић, налази и накнадно руком забележено место, Сарајево, и датум, 1. новембар 1922. (курзив С.О). Да ли је поштанска пошиљка која је садржала овај препис, а која је Милутину Миланковићу пристигла само пар дана пре сусрета са његовим колегом Шевићем, послужила као тема за разговор и иницирала даљу сарадњу, не можемо да тврдимо, али, да је Шевић у новембру 1922. дошао до докумената која су га навела да и пред крај децембра исте године настави своју потрагу за осталим делима Уроша Миланковића, чини се као чињенично стање.

3 У пост-скриптуму писма од 19. фебруара 1927, Милутин Миланковић нуди, преко Марка Малетина, Васи Стајићу: „(...) Weltorganismums и Просвейу човека, а сем тога и биографију Уроша Миланковића, исписану руком његова брата Димитрија пуковника, и свежањ оригиналних писама и других докумената Урошевих“ (КовАчек 2005: 47). По писму Васе Стајића од 14. маја 1927 (КовАчек 2005: 56), којим Милутина Миланковића обавештава да
} 
материјале напослетку поверио Милошу Радојчићу, који је напокон и написао студију, која опет није имала среће да буде публикована у Лейойису Матице српске ${ }^{4}$. Напослетку, рад под називом Философија Уроща Миланковића штампан је у пет наставака у часопису Уйознај себе у Београду 1933. године. Ова, а потом и студија Миодрага Поповића Урощи Миланковић, име нейравично заборављено из 1954, навеле су и Илију Мамузића да 1982. прилогом Уром Миланковић - наш мислилаи (којег карактерише чињеница да се више од шездесет реченица тога текста завршава узвичником, оп. С.О) реактуелизује питање рецепције дела овог филозофа. Пратећи Мамузићева запажања и следећи пут из есеја Андрије Стојковића О генези филозофских йојмова Уроща Миланковића, Иво Тартаља својим је приређивачким радом спасао од заборава поезију Уроша Миланковића. Након што је питање датирања и ауторства преписа наведене поезије решено, желимо овим текстом да скренемо пажњу и на још једну страну личности њенога аутора, представљену кроз писма породици, у којој видимо Уроша Миланковића као правог представника српског грађанства прве половине деветнаестога века.

4. СПИСИ УРОША МИЛАНКОВИЋА ИЗ РУКОПИСНЕ ЗАОСТАВШТИНЕ МИЛАНА ШЕвићА. Водећи се методом која је и установила чији је аутограф у питању, пре преласка на централну тему нашега рада, побројаћемо доступне најрелевантније прилоге који ће примерима илустровати у овом тексту заступане ставове. У фасцикли насловљеној Урощ Миланковић, белещке (инв. бр. М. 10. 875), која се чува у Рукописном одељењу Матице српске међу осталим рукописима Милана Шевића, сви ови списи доступни су заинтересованима. Фасцикла садржи документа која су централна тема нашег рада, преписана писма која је Урош Миланковић, у време своје службе у аустријској војсци, слао родитељима из Нове Градишке и Ђенђеша у Даљ, у периоду 1827-1830, али и остале списе који су нам били од помоћи. Увидом у ова документа, јасно се види да је исти рукопис и при насловљавању фасцикле и библиографским исписима који се налазе на осталим листовима и афишама, као и при препису поезије и самих писама. Поред тога, у самом тексту писама, приметно је да је преписивач водио рачуна да будућим приређивачима сачува до у детаљ све појединости оригиналног текста. У писму од 14. октобра 1827, преписивач се посебно потрудио, правећи у своме препису и ручну

је примио у Матици пакет са тридесет и шест докумената, видимо да он обећава да ће се латити посла, међутим, ни овога пута тај рад није дао конкретан резултат.

${ }^{4}$ Сам Милутин Миланковић узео је на себе улогу посредника и предложио ово дело за објављивање Лет̄ойису Матице српске (КовАчек 2005: 102), али је Никола Милутиновић (од 1933 до 1945. секретар, а од 1933 до 1941, са краћим прекидом, и уредник Лейойиса), по сачуваном концепту за одговор на наведено Миланковићево писмо (КовАчек 2005: 103), одбио. Иако заиста по своме обиму студија не спада у материјале које је оновремена концепција нашег најстаријег активног књижевног часописа доносила као прилоге, нејасно је да барем малим прилогом или изводом из ове студије Лейойис није нашао за сходно да скрене пажњу својих читалаца на деветнаестовековног филозофа. 
подножну напомену, као и доносећи на истом папиру и интегрални текст једнога писма, као и адресу на која су сва три писма послата, уз речничко тумачење појединих латинских речи са стране. Међу истом грађом, доступан је и поменути животопис Уроша Миланковића, који је на ћириличкој писаћој машини прекуцао Богдан Миланковић у Сарајеву 1922. године.

5. Писма УРОшА МилАНковићА РОдитељимА. Након што смо дефинитивно утврдили и ко је писац, али и ко је преписивач у случају Шевић-Миланковић, доносимо и савремену транскрипцију самих писама (прилози 1.1, 1.2. и 1.3).

Прилог 1.1: Покушај транскрипције писма од 5. марта 1827.

Љубезнјеиши родитељу!

Овај час прими ваше дражаеше писмо и не могу ни минут пропустити, да вам таки не пишем, да се дражаеши Родитељу у пуној мери здравља находим, са величаешим соболјезнованијем разумје да сте тако боловали, и могу себи представити колико сте које чрез болести, а особито чрез крвопролитија ослабити морали, но фала Богу милосердјеишему што вам је мени дражаеши живот сохранио. Што се прочу мог обстојатељства тиче, знате шта је служба и служба са безчиселними одговори ограничена, но ја сам фала Богу задовољен и са овим задовољан. Колико је иоле могуће, чувам своју младост, по највећој могућности извршавам моју службу, сваком и несретном случају човек предусрети не може, зато прочем колико је могуће држим се филозофије здравог разума, пак како Бог да. Колико сажаљујем да сте боловали дражаеши Родитељу, толико се радујем да сте Богу хвала оздравили, и радујем се да ћете с Божијом помоћи у настапајуште време пролећа које све оживљава ваше крјепости, које ви љубезнјеиши Оче и млого и још дуго потребујете, повратити, и да ћу вас ако нам Бог свима здравље и живот буде даровао, може бити на лето на један ускок посјетити, и здрава и весела са Г. Матером и прочом нашом фамилијом затећи. Сто сам пута и скоро сваки дан мислио да Вам пишем, па кад дођем у канцеларију сваки ме пут опет послови тако окупирају, да од дана на дан одлагивајући, до данас писати вам закасни са свим (sic!).

Менја отеческој љубави препоручујући остајем вам покорнјеиши син Урош Миланковић У Новој Градишки, 5га марта 827.

Прилог 1.2: Покушај транскрипције писма од 14. октобра 1827. Љубезнјеиши родитељу!

Не сумњам да ће вам драго бити опет наскоро од мени разумети будућ да и тако моје прво писмо у хитности написао јесам. Шта вам друго писати могу, него да сам Богу хвала здрав и у свему задовољан. Прошастог месеца имали смо Concentrirung und Musterung, гди сам прилику имао, све официре Регименте, и сву Регименту познати, врло ми се допада слога међу официрима и искрен начин обхожденија. Какогод што сам ја задовољан тако са 
Региментом, тако се надам ће и она самном задовољна бити. Оберштер ми је већ толико воверенја у мени, и особито одликованије указао, да ми је мало и противно било, јербо лако завист и гонение родити се може, кога се ја опет поред мог управо мислећег и творећег карактера бојати се толико немам. У овој сам вароши још слабо познат, поред млогог посла, кога сам примио, док у ред не дођем, слабо се са цивилистама ове вароши обхождавати, и познанства правити могу. Овде се много говори да ћемо на пролеће (кратак део реченице не немачком језику нечитак, оп. С.О.) на границу марширати. Берба је овде била плодна, особито леп почетак јесени имамо. Желим да вас ово моји неколико речи у здрављу нађу. Све вас љубезнјеише поздрављајући остајем Ваш покорнјеиши син

Урош Миланковић, OberlttAuditor при PalatinalHussarenRgmt У Генгешу, 14га октобра по Римском 827

Адреса: Perilusstri ac generoso Domino Theodoro Milankovits, Iuctyti Domini Dalja Domino Rationista mihi singulariter colonissimo, per Pesth - Wukowar, a/ Dalja

Прилог 1.3: Покушај транскрипције писма од 9. јануара 1827.

Љубезнјеиши родитељу!

Највећа је моја жеља, да Вас ово моје писамце у здрављу и задовољству затече, да идућу годину и још млоге и млоге године у кругу ваши Вас највише љубећи чада, заједно са вашом госпојом супругом нашом добром Матером увек у здрављу, и задовољству проведете. Знам да у овом оскудном времену због одержанија свију ваши млого бриге носите, но опет зато нећемо се у понор пустити, отимаћемо се колико можемо и како можемо. Удар ови оскудни времена, као што вам је познато љубезни Родитељу, осећају и друге и јаче фамилије. Ја сам фала Богу са свим здрав и веома задовољан, може бити да ћу имати увесељеније на пролеће ил у лето на два три дана Вас посетити, јер на кратко време од Регименте одсуствовати могу, или може бити да ћу се с пештански ђаци на факацију доћи, да се сви заједно састанемо и неколико дана весело проведемо. Код Милитарије сад све новине престануше, код нас је сад највећа новина да нам снег једнако пада, и курјаци већ у варош долазе, и да марва непрестано и великим числом гине. Писали су ми и ђаци из Пеште и Мито из Врбаса, овом солдату још нисам одговорио, док научи немецки, мораће маџарски учити. Код Маџарске гавалерије биће у четвртој најдуже петој години, а може бити и пре официр, као што код наше регименте бива. За цулаг ћемо се бринути само кад официр постане, први equipirung и кола мораће му трговци помоћи. Нек се здраво труди лепо писмо добити и добро немецки писати, наш Обрштер много држи (део реченице написан на нечитком немачком језику, оп. С. О). Сада вас све љубезнејши поздрављам осватајем ваш покорнјеиши син

Урош Миланковић, Oberltt und Auditor aus lübe. KK. Palatinal 12te Hussaren Regimenth У Генгешу, 9га јануара по Римском 1830. 
6. НАВОДИ ИЗ ЈЕДИНОГ У ЦЕЛОСТИ САЧУВАНОГ ПИСМА УРОША МИЛАНКОВИЋА ЉудЕвиту ГАЈу. Три вредна документа српске пречанске историје приватног живота, која сведоче о степену учености грађанске класе и јасно показују њено опхођење са старијим члановима породице, упоредићемо сада и са детаљима јединога у целости сачуваног писма које је Урош Миланковић из Ђенђеша 1. марта 1842. послао Људевиту Гају у Загреб. Цитате из овога писма доносимо наведене према препису у делу Јосипа Хорвата и Јакше Равлића Pisma Ljudevitu Gaju (HoRvAT-RAvLIć 1956: 321):

(...) Vašeg su Blagorodia trudi i zasluge za ugnjetenu našu braću hristiansku u Turskoi i za, protiv svakoga nepriatelja, sojedinjenju našu krjepost narodnju, odviše poznate, nego dase nebi smeo usuditi, našem Voždi slavnom, ovo na nemačkom jeziku spisano djelo preporučiti, i moliti, dabi milost imali, cenzure radi poclati ga gospodinu Cenzoru, preporučiti ga. U prvoi se časti radi o odnosu Turske ka Evropi, i o izbavlenju naši braća Hristiana ispod jarma turskog. U drugoi se časti radi o pravama i o slobodi narodnjoi, o nepravdi ugnjetavanja, i naročito denacionalisiranja narodnjeg, i o krjeposti sloge i sojuza. Ja se usućujem Vaše Blagorodie dalje moliti, dabiste milost imali ovo od mene kao nepoznatog Vašem Blagorodiju, kao velikom mužu narodnjem u osobitom počitaniju preporučito djelce, pored vašeg mogućstva promovirati (..). Ja osobito molim gospodina Censora, dabi ga censurirati uskorio, buduć da ja u Slavoniu otlazim, gdise nemogu dugo zadržavati, i gdi ga štampati namjeravam. (...)

7. ПИСМА УРОША МИЛАНКОВИЋА РОДИТЕљИМА КАО ПРИЛОЗИ ЗА ИЗУЧАВАњЕ ИСТОРИЈЕ ПРИВАТНОГ ЖИВОТА СРПСКОГ ГРАЋАНСТВА У ПРВОЈ ПОЛОВИНИ 19. ВЕКА. Ако самеримо писма Уроша Миланковића са великим корпусом писама обрађених при истраживањима историја приватног живота прошлих епоха, већ на први поглед можемо уочити да она беспоговорно следе установљени систем. У писмима које тада двадесетседмогодишњи и тридесетогодишњи професионални војник Дунавске монархије шаље родитељима, очигледни су традиционални обрасци понашања у писаној комуникацији онога времена. Ти обрасци су „подразумевали и одређене хијерархијске односе - ко зна, може и сме да пише и чита писмо“ (Лукић КрстАновић 2006: 48), те је према томе и јасно да у овом случају путем њих комуницирају отац и најстарији његов син, иако су сва та писма „на неки начин била заједничка добра породице, која су имала проходност код свих чланова“" (Лукић КрстАновић 2006: 48). Писма Уроша Миланковића су „својеврсна надградња у традиционално схваћеној схеми унутарпородичних односа“ (РАдуловић 2006: 5), а њихови „модели обраћања, сведени на конвенцију и наизглед испразно информисање о добром здрављу које и вама желимо, заправо исказују бригу и поштовање за своје ближње“ (Ромелић 2006: 19).

Сва писма послата су на адресу забележену на другом писму, која на латинском језику гласи:,Perilusstri ac generoso Domino Theodoro Milankovits, Iuctyti Domini Dalja Domino Rationista mihi singulariter colonissimo, per Pesth - Wukowar, a/ Dalja,“ а у нашем слободном преводу значи „Угледном и пле- 
менитом господину Теодору Миланковићу, велепоседа даљског господину благајнику и појединачном пољопривреднику“5. Језгро породице, смештено на овој адреси очинског дома у Даљу, било је увек тачка са које се полазило и у коју се враћало, а када се из њега дуже или краће избивало, комуникација путем поште била је обавезна.

Писма која је Урош Миланковић писао родитељима, јасно сведоче и о његовом личном развоју у трогодишњем периоду у којем су настала. Од богобојажљивог млађег члана породице, до самоувереног и успешног војника са чином, који дели савете и млађима и старијима, пут је који је овај стваралац прошао и који је документован у овој писаној оставштини.

У првом писму, на чак шест места споменут је Бог (,фала Богу“, „фала Богу милосердјеишему“, „како Бог да“, „Богу хвала“, „с Божјом помоћи“, „,ако нам Бог свима здравље и живот буде даровао“), док се у помоћ и заштиту више силе у наредна два писма аутор позивао само по једном, пишући да је „Богу хвала здрав и у свему задовољан“, односно „фала Богу са свим здрав и веома задовољан“. Прво писмо оптерећено је колико богобојажљивошћу, толико и прикладним свуда присутним и потенцираним поштовањем

5 Поменути господин, у сећањима свога праунука Милутина Миланковића описан је на више места, у којима се наводи како је „рођен 1769, умро 1841“, те како „свршио је правне науке и, живећи на свом имању у Даљу, био каснар тамошњег патријаршијског властелинства“ (МилАнковић 1997: 35). Портрете Тодора Миланковића насликали су и два значајна српска сликара, његов суграђанин Јован Исајловић Млађи (1803-1885) и портретиста кнеза Милоша, Вука Караџића и митрополита Стратимировића, Павле Ђурковић (1772-1830). Исајловићево дело „представља Тодора као отменог грађанина бидермајерског доба, обријане браде и бркова, одевеног претечом садашњег фрака и белим прслуком (...) Својим илтелигнетним лицем, високим челом, озбиљним мирним погледом својих црних очију и лаким осмејком око стиснутих усана, оличава ми његов лик велико доба Стратимировића, почетка наше просвећености“" (МилАнковић 1997: 37). И сам високо образован, Тодор Миланковић настојао је да највише образовање приушти и својим потомцима, о којима опет најбољу забелешку налазимо код Милутина Миланковића који, у нешто каснијем тренутку у времену у односу на Урошева писма, о овој генерацији своје породице бележи: „Из списка пренумераната Урошева дела Просвјеш̄а човека види се шта су била његова браћа 1847. године, када је то дело штампано у штампарији јерменског манастира у Бечу. Ту се спомиње његов брат Тома као фишкал дијецезе пакрачке и главне пожешке вармеђе присједатељ, брат Георгије, као славног доминијума у Даљу рентмајстор и адвокат, брат Марко, назван у калуђерству Методије, као епископски протосинђел, члан честне консисторије и професор богословије, брат Димитрије, као први писар управитељства вароши Београд. Пети брат Урошев, мој деда Антоније, спомиње се без икаквог ближег означења.“ (МилАнковић 1997: 37). (Деда Милутина Миланковића, Антоније звани Анта, утемељивач је трговачке радње која је од мале породичне фирме постала, пре свега радом Милутиновог оца Милана, успешна компанија, која се „брзо развила и годинама је имала доминатан положај не само у Даљу већ и у целој околини, урачунавајући у њу и оближња села Бачке“ (МилАнковић 1997: 41), оп. С.О). Породици која је дала овакве потомке, припадао је и Урош Миланковић, те не чуди и његов озбиљан и учен тон у писмима, али ни велика брига и за млађе и за старије, јер се чини да су Миланковићи, радећи сложно и саветујући се међусобно, и постигли ове велике резултате. 
према мушком родитељу, којег син апострофира једнак број пута колико и Свевишњег, називајући оца „љубезнејши родитељу“, два пута „дражаеши родитељу“, ,љубезнејеиши Оче“, себе додатно још унижавајући прикладним завршетком писма „Менја отеческој љубави препоручујући остајем вам покорнјеиши син“. Готово средњовековни тон обраћања у овоме писму, у коме се види колико је сину стало до очевог мишљења, садржи још једно констатацију која на прво читање упада у очи: „колико је могуће држим се филозофије здравог разума, пак како Бог да.“ Из ове реченице јасно је видљиво и да син пише општеобразованом оцу, и да његово помињање Декартове филозофије подразумева и саговорника који разуме о чему му се пише, без потребе за подробнијим објашњењима. Оцу који зна „шта је служба и служба са безчиселними одговори ограничена“, син не мора да разлаже да на своме радном месту настоји да све прима критички и као истину узима само оно што се уочава јасно и разговетно (clare et distincte). У првоме писму такође, син оцу жели да нагласи да су га канцеларијски послови и обавезе преокупирали, те да није могао да нађе прикладно време и простор у коме би се у писаној форми обратио породици и известио их о своме стању, чиме се такође потврђује да је писање писама „индивидулани чин у колективној комуникацији“" (Лукић КРстАновић 2006: 47) које обавезно следи и образац да „Писање има своје ритуалне просторе често изоловане у тишини или самоћи“ (Лукић КрстАновић 2006: 47).

У другом и трећем писму, већ је приметно да сада већ искусни канцеларијски службеник, који службује и у новом граду и међу другачијим колегама, писма пише са великим олакшањем. Већ шест месеци након првог сачуваног писма, премештен са службом у друго место, из Нове Градишке у град Ђенђеш у Мађарској, он главнину писма посвећује вестима из регименте и своме сналажењу у новој средини. Реченице ових писама лакше су, неоптерећене строгом формом првог писма, информације у њима јасније су и директније. При крају другога писма, послатог у октобру из једног ратарског и виноградарског краја у други, син родитеље обавештава и да „Берба је овде била плодна, особито леп почетак јесени имамо“6. У трећем писму, најстарији син узима на себе слободу да дели савете млађој браћи, превасходно брату Мити који је на војној школи, а не либи се ни да барем покуша да утеши оца, апелујући на тешка и оскудна времена која „осећају и друге и јаче фамилије“. Факација на коју ће ићи пештански ђаци, односно његова млађа родбина, и прилика да се сви поново окупе у родној кући у Даљу, заиста радује младог официра, коме више војнички живот не представља ни велику новину, нити задовољство, те извештава и да „Код Милитарије

${ }^{6}$ У завичају Уроша Миланковића, у Даљу, (одакле је и аутор овога текста), по Ђенђешу, граду у Мађарској у коме се филозоф у војној служби налазио, назива се и сорта раног, слатког грожђа, званичног имена јулски мускат. Исти пример налазимо и у Речнику срйских говора Војводине, у коме се наводи: „ちенђещ м 'врста раног грожђа'; - У винограду има пуно ђенђеша (Бг - СрК; НС)““ (РСГВ 3 2003: 14). 
сад све новине престануше, код нас је сад највећа новина да нам снег једнако пада, и курјаци већ у варош долазе, и да марва непрестано и великим числом гине“. Урош млађег брата Миту индиректно саветује шта и како да поступи у наредним корацима своје каријере, које је он већ прошао и о којој зна довољно да може да умирујуће делује и на остале укућане. Одговоре на питања из братовљевога раније примљеног писма које помиње, одабире да не пошаље директно пошиљаоцу, брату Мити, него оцу. То чини, јер је искусан у војној коресподенцији, те оставља глави породице могућност да поново саветом делује као најстиарији йо чину и да његов ауторитет не буде доведен у питање ни у тренуцима у којима породица трпи жртве због оскудних времена.

8. ПРЕПИСКА УРОША МИЛАНКОВИЋА И ЉУДЕВИТА ГАЈА КАО ПРИМЕР УЧЕНЕ ПОСЛОВНЕ КОРЕСПОДЕНЦИЈЕ ЕПОХЕ. Дванаест година након писама које је послао породици, Урош Миланковић из истог места пише и Људевиту Гају. ${ }^{7}$ У писму вођи илирског покрета, писаног латиницом и језиком прикладним за комуникацију за примаоцем, видимо филозофа у позицији аутора забринутог за судбину свога дела. Наиме, књига или брошура којој прети цензура и забрана објављивања, те се њен аутор из истих разлога и обраћа утицајном Гају у Загреб, бави се односом Турске ка Европи, односно у њој Урош Миланковић пише о ,,izbavlenju naši braća Hristiana ispod jarma turskog“, посебно се бавећи темама „о pravama i o slobodi narodnjoi, o nepravdi ugnjetavanja, i naročito denacionalisiranja narodnjeg, i o krjeposti sloge i sojuza“. На помисао да је реч о брошури, наводи нас то што аутор своје дело назива „djelcem“ али још више то што Гаја, иначе у том тренутку и власника штампарије, у нецитираном делу писма моли да му назначи „,enu za jedan tabak u 2000 dve hiljade egsemplara“. Као што после сазнајемо, из препричаног остатка коресподенције у изворном делу (HoRVAT-RAVLIĆ 1956: 322), прво Урош Миланковић из Беча 15. маја 1843. моли Гаја да промовише објаву његовог дела, а затим сазнајемо и да је дело цензура забранила (писмо из Беча 18. јуна 1843). Писац потом моли штампара да му рукопис врати, након чега 10. децембра имамо и Гајеву потврду из Загреба да је рукопис под насловом Die Emanzipation, der Kampf des Lichtes mit der Finsterniss, der allgemeina Sieg der Freyheit послао аутору назад у Беч.

У овоме писму, Урош Миланковић се саговорнику обраћа са „Visokopočitaemi gospodine“, називајући га и „Vaše blagorodie“" и „,naš Vožda slavni“.

\footnotetext{
${ }^{7}$ Иако животопис Уроша Милнаковића који је написао његов брат Димитрије тврди да је због проблема са обршитаром Урош Миланковић тражио и добио пензију 1835, те одступио са места аудитора и преселио се прво у Трст, а затим у Беч, што је податак који се од тада преузима у готово свим објављеним његовим биографијама, ово писмо послато је из истог места и потписано истим чином који је Урош Миланковић имао и у последњем писму родитељима, „U. Milanković, C.K. auditor U Gengešu, 1-a Marta 1842.“ Да ли је ово нов податак за његову биографију, остаје нам да покушамо да откријемо, али већ наредна писма послата истом примаоцу у Загреб, од којих су сачувани само сажеци, као и Гајев одговор на њих, налазе пошиљаоца наредне године на новој, бечкој адреси.
} 
Иако нису лични познаници, филозоф се не либи да се обрати књижевнику, познајући Гајеве „trudi i zasluge za ugnjetenu braću našu hristiansku u Turskoi i za, protiv svakoga nepriatelja, sojedinjenu našu krjepost narodnju“. Научен у школи, а посебно у касарнама, да службена коресподенција започиње неизоставним титулирањем, након обавештења о теми своје молбе, можемо у овом писму да видимо и предузетног Уроша Миланковића, који открива и праву природу свога дописа, пословну понуду власнику штампарије. У жељи да споји лепо и корисно, да у исти мах прође цензуру али и пронађе издавача, Миланковић се обраћа на место на којем спајање лепог и корисног такође иду руку под руку, али без успеха. У ситуацији у којој је жељена обострана корист, аустријска цензура показала се као надмоћнија, те до штампања овог дела није дошло, али је сведочанство о још једној страни филозофове личности и о још једном виду његове писне комуникације сачувано.

Језик свих Миланковићевих писама сличан је језику поезије и прозе истога аутора. Понекад се аутор својим стилом прилагођава форми, те на почетку и на крају свих писама имамо облике из старијег периода развоја језика, а понекад га, кориштењем облика прикладнијих западној варијати развоја језика, филозоф интенционално прилагођава примаоцу, Људевиту Гају. Поред писама писаних породици, у којима се види јасан развојни пут јаке стваралачке индивиде, зауздане аустријском официрском униформом, видимо у преписци са Гајем и официра који се, на исти начин на који би водио и службену преписку, обраћа и потенцијалном партнеру у издавачком послу.

9. ЗАкључАк. Три писма Уроша Миланковића из рукописне заоставштине Милана Шевића, као и пословна преписка Миланковића и једне од средишњих фигура панславистичког Илирског покрета, Људевита Гаја, доносе нам још један поглед на живот и стваралаштво овог аутора. Објаснивши судбину оригиналних Миланковићевих рукописа и њихових преписа, те детаљно анализирајући три његова приватна, те једно више пословно писмо, понудили смо једно ново читање заборављене грађе, која ипак има вредност, по нама, прворазредног сведочанста о њеном аутору. Писма Уроша Миланковића сведоче нам о приватној преписци као виду породичне и пословне комункације, у којој можемо да реконструишемо поједине аспекте свакодневног приватног живота њиховог аутора. Поред до сада већ представљених доступних и сачуваних филозофских дела, али и недавно откривене и реактуелизоване поезије Уроша Миланковића, сада можемо, иако на малом узорку, да упознамо овог аутора и као приватну и јавну личност свога времена, као члана једне грађанске породице и као писца посвећеног судбини својих дела. 


\section{ИЗВОРИ И ЦИТИРАНА ЛИТЕРАТУРА}

КовАчек, Божидар. Милуӣин Миланковић и Майица срӣска. Нови Сад: Матица српска, 2005.

Лукић-КрстАновић, Мирослава. Кутак за животне приче: писма, дневници и мемоари. Живка Ромелић (ур.). Ми смо добро щйо и вама желимо: ирривайна йрейиска као вид йородичне комуникације. Крушевац: Народни музеј Крушевац, 2006, $45-55$.

МАмузић, Илија. Урош Миланковић, наш мислилац. Зборник Майице срӣске за књижевности и језик XXX/3 (1982): 417-426.

Миланковић, Милутин. Усйомене, доживљаји и сазнања. Александар Рибникар (ур.). Београд: САНУ, 1997.

РАдолчић, Милош. Филозофија Уроша Миланковића. Уӣознај себе 7, 8, 9, 10, 12 (1933).

РАдуловић, Ема. Предговор. Живка Ромелић (ур.). Ми смо добро шит̄о и вама желимо: иривайна ирреииска као вид йородичне комуникачије. Крушевац: Народни музеј Крушевац, 2006, 5.

РСГВ 3: Речник срӣских г̄овора Војводине. Свеска 3: Ђ-J. Миодраг Поповић (ред.). Нови Сад: Матица српска, 2003.

Ромелић, Живка. Из историје приватног живота у Србији: Ми смо добро што и вама желимо, приватна преписка као вид породичне комуникације. Живка Ромелић (ур.). Ми смо добро шитио и вама желимо: иривайна ирреичска као вид йородичне комуникације. Крушевац: Народни музеј Крушевац, 2006, 6-26.

Поповић, Миодраг. Урош Миланковић, име неправично заборављено. Једна йесма и једна ейоха. Београд: Ново покољење, 1954, 127-161.

ТАртАљА, Иво. Награда Младен Лесковац. Лейойис Майице срӣске 496/6 (2015): 849-851.

ТАРтАљА, Иво. Откриће песама Уроша Миланковића (1800-1849). Зборник Майице срйске за књижевности и језик LXIII/2 (2015): 571-582.

ХАџић, Зорица. Како смо маргинализовали Милана Шевића. О Милану Шевићу. Нови Сад: Академска књига, 2017, 15-24.

Шевић, Милан. Дневници. Кюиг̄a 1. Зорица Хаџић (ур.). Нови Сад: Дневник, 2013.

Шевић, Милан. Дневници. Кюиг̄a 2. Зорица Хаџић (ур.). Нови Сад: Дневник, 2014.

Шевић, Милан. Др Милан Шевић: Урощ Миланковић, белещке. Рукописно одељење Матице српске у Новом Саду, синг. инв. бр. М. 10. 875.

StoJković, Andrija. O genezi filozofskih pogleda Uroša Milankovića. Provincija 47 (1987). Horvat, Josip, Jakša Ravlić. Pisma Ljudevitu Gaju. Građa za povijest književnosti Hrvatske 26. Zagreb: JAZU, 1956. 
Srđan V. Orsić

\title{
THE LETTERS OF UROŠ MILANKOVIĆ FROM THE MANUSCRIPTS OF MILAN ŠEVIĆ
}

\author{
Summary
}

In order to support the reaffirmation and re-actualisation of the works of philosopher Uroš Milanković (Dalj 1800 - Vienna 1849), from the manuscript legacy of Milan Šević, in this work, we bring three original letters that he sent as a soldier to his parents, and the details from his written correspondence with Ljudevit Gaj, one of the central figures of the pan-Slavist Illyrian Movement. Explaining the fate of the original Milanković's manuscripts and their transcripts, and analyzing in detail three of his private and one business letter, this paper offers a new reading of the forgotten material, which has the value of first-class evidence of its author and the time in which it was created. The letters of Uroš Milanković testify about private correspondence as a type of family and business communication, in which we can reconstruct certain aspects of the daily life of their author. In addition to the previously presented available and preserved philosophical works, as well as the recently discovered poetry of Uroš Milanković, we can now introduce the philosopher as a private and as a public figure of his time: as a typical member of a Serbian citizen's family of the first half of the nineteenth century, and as a writer dedicated to destiny of his works.

\author{
Универзитет у Новом Саду \\ Филозофски факултет \\ Одсек за српску књижевност \\ Др Зорана Ђинђића 2, 21000 Нови Сад, Србија \\ srdjanorsic@gmail.com
}

